\title{
The Geologic Time Scale and the Italian stratigraphic record
}

1 Dipartimento di Geologia, Paleontologia e Geofisica, Università di Padova, Via Giotto 1, I-35137 Padova, Italy.

2 Dipartimento di Scienze della Terra, Università di Milano, Via Mangiagalli 34, I-20133 Milano, Italy.

The construction of the Geologic Time Scale (GTS) is a titanic scientific challenge that has been under way for two centuries and will require much dedicated effort in the future. Italy preserves a paramount stratigraphic record of Mesozoic and Cenozoic marine sediments that have been significant in the development of the modern GTS. The Italian stratigraphic record has been historically important in introducing and defining the standard Chronostratigraphic Units (CUs) of the Neogene and Quaternary. Pelagic successions from Northern Apennines and Southern Alps have been used in the seventies for integrating the late Cretaceous-Paleogene Geomagnetic Polarity Time Scale (GPTS) with planktonic microfossil biostratigraphy and standard CUs. This was a major contribution to the construction of a new generation of GTS based on integrated magnetobiochronology. The middle Miocene to early Pleistocene marine record from Sicily and southern Italy has been fundamental for establishing the recently developed Astronomical Time Scale (ATS). In prospect, there are many potentials still to be exploited in the Italian marine stratigraphic record for implementing the GTS by defining GSSPs of various CUs, improving magnetobiochronology and extending downwards the ATS.

\section{Introduction}

The central role of time in Earth sciences can hardly be overstated. We need time as a relative age vernier (Chronostratigraphy) for unraveling and chronicling the Earth's and life's evolution. We need absolute time (Geochronology) if we want to understand and model processes like rates of tectonic deformation or organic evolution or the loops of the global climatic system. Indeed, geoscientists have been confronting with the problem of time since the foundations of the discipline, and we like to think that the achievement of the concept of deep geologic time, well beyond the biblical chronology, is a major contribution to the modern weltanschaung (Gould, 1990). Actually, the "discovery" of deep geologic time, although badly needed and perceived by geologists and paleobiologists like Darwin, has been definitively achieved only in the 20th century with the discover of radioactivity. The birth of Geology in the first half of the 19th century and successive developments are strictly interwoven with the construction of a Geologic Time Scale (GTS), which represents the standard and common language for Earth scientists for achieving most of their goals. The modern GTS in essence is composed of two distinct scales: the relative time scale (Chronostratigraphic Units, CUs) and a chronometrical or so-called absolute time scale (Geochronologic Units, GUs). Its construction has been and still is fraught with many obstacles, which include the limits of the stratigraphic data base; the accuracy, precision and reliability of correlation and dating tools; and, last but not least, problems of nomenclature, procedures and stratigraphic philosophy. However, the GTS is an ongoing enterprise because our need of accuracy and precision in dating and correlation is ever-increasing and, because, even the apparently easily achievable goal of an internationally agreed upon set of standard CUs has not yet been accomplished.

In retrospect, the development of the modern GTS is punctuated by five major breakthroughs that resulted in quantum improvements in our ability to read geologic time:

The origins: the Paleontologic Time Scale. In the first half of the 19th century, the application of two simple paradigms, the principles of superposition of Steno and of faunal succession of Smith, led to construction of the first GTS, establishing the large-scale basic chronostratigraphic subdivisions of the GTS that are still in use. Finer subdivisions (what we now call "stages"), based on megafossil biostratigraphy, were added in the second half of the 19th century, although within a much confused conceptual and terminological framework.

Radiometry: the Geochronologic Time Scale. With the discovery of radioactivity at the end of the 19th century, the way was open to the dating game of the traditional CUs and the foundation of the modern GTS (Holmes, 1960).

Magnetobiochronology: the Geomagnetic Polarity Time Scale (GPTS). Up to the early 1970s, the chronology of the GTS was based only on sparse radiometric dates of CUs. In the 1960s, a major breakthrough was represented by the integration of the GTS with the history of polarity reversals of the geomagnetic field (GPTS), initially based on lava flows and marine magnetic anomalies. The drilling of oceanic sediments, development of detailed multiple biostratigraphies based on planktonic microfossils, and technologic advances in measuring magnetic properties of sediments led to a new generation of GTS with improved chronology based on the calibration of biostratigraphic events via magnetostratigraphy (magnetobiochronology) (e.g. Harland et al., 1982; Snelling, 1985; Berggren et al., 1995).

Cyclostratigraphy: the Astronomical Time Scale (ATS). In the early 1990s, advancements made it possible to accomplish a centuryold dream of geologists: to utilize the pervasive cyclicity of the stratigraphic record for deriving a chronology. In particular, in the most recent part of the GTS (the icehouse world of the Pleistocene), it has been proved beyond any reasonable doubt that sedimentary, geochemical and paleontologic cycles are related to Milankovich climate change from variations of Earth's orbital parameters, the chronology of which is well established in the most recent geologic past. An unprecedented tool for dating events in the geologic record became available with the construction of an Astronomical Time Scale (ATS; Shackleton et al., 1990; Hilgen, 1991). The chronology of the ATS is independent of radiometry (Hilgen et al., 1997).

The GSSP concept: procedures, nomenclature and philosophical approach to the GTS have always been contradictory and confused. The need of a uniform terminology and philosophical approach was felt early on and first attempted at the International Geological Congress of Bologna in 1881. However, it has not been until the early 1970s that, thanks to the dedicated effort of Hollis Hedberg, an international agreement has been achieved, although not universally accepted, with the publication of the "stratigraphic guide" (Hedberg, 1976). With reference to the GTS, of utmost 
importance has been the introduction to the practice of defining each CUs in the rock record by a boundary stratototype section, later refined as Global Stratotype Section and Point (GSSP; Cowie et al., 1986). The GSSP concept is intended to provide a formal and unequivocal definition in the rock stratigraphic record of the CUs of the GTS by means of an international agreement.

Our aim here is to review the role of the Italian stratigraphic record in various accomplishments outlined above and comment on ongoing work and prospects for the future.

\section{The Italian stratigraphic record}

Italy, in spite of its small size, is characterized by a varied, geodynamically very active geological landscape that has been the cradle of many geologic concepts from stratigraphy to geodynamics (Krijgsman, 2002). In particular, two marine stratigraphic records in Italy have been of cardinal importance for the GTS: the Mesozoic Tethys pelagic record and the Neogene-Quaternary Mediterranean record.

\section{The Tethys pelagic record}

During late Triassic and early Jurassic times, the fragmentation of Pangea resulted in the opening of a large ocean known as Tethys, that separated Eurasia from Africa and the southern continents. Tethyan sediments deposited on the margins of southern Europe and northern Africa make up the bulk of the Alps and the Apennine orogenic belts. A large part of these sediments have been disrupted by tectonic processes but the pelagic record of the African margin (Adria promontory) is well preserved in the Apennines and Southern Alps. In particular, an almost complete pelagic record that spans from the early Jurassic to the early Miocene is preserved in the northern Apennines of central Italy (Marche and Umbria regions; Figure 1). This record, containing plenty of various marker fossils, good magnetic properties, widespread volcanic material and lithologic cyclicity, has been critical in fostering the development of magnetobiochronology (Alvarez et al., 1977; Lowrie et al., 1980), and it is suitable for defining GSSPs.

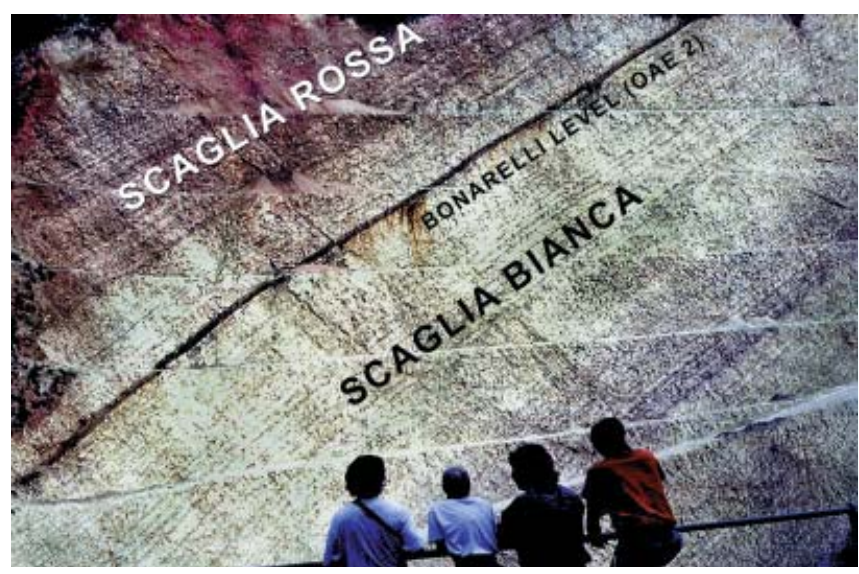

Figure 1 The Tethys pelagic record of Northern Apennines in the Vispi Quarry in the Contessa Gorge, near Gubbio. The prominent dark organic-rich Bonarelli Level corresponds to the latest Cenomanian Oceanic Anoxic Event 2. In the nearby classical Gubbio section iridum anomaly at the $K / T$ boundary was first recognized.

\section{The Mediterranean record}

The Mediterranean Sea is a relatively recent geologic vestige of the collision of Europe and Africa-Arabia plates, which led to the consumption of most of the Tethys oceanic crust and to a progressively more severe connection with the global ocean. The AfricaEurope collision resulted in thrust-belts, large extensional basins, diverse tectonic arcs. The disruption of the connection with the IndoPacific Ocean during the Miocene and the severe progressive restriction of the connection with the Atlantic Ocean since late Miocene, resulted in a semi-enclosed marginal basin that acts as an amplifier of the climatic system. The Mediterranean marine stratigraphic record has thus become an unique archive of the evolution of the Earth climatic system. As far as Italy is concerned, its tectonic shaping is strongly related to the opening of the Algero-Balearic basin during the early Miocene and, overall, to the opening of the Tyrrhenian Sea from the late Miocene to the Pleistocene. Most of the Italian peninsula and Sicily have been uplifted during the Pleistocene providing incredible exposures of late Neogene and Quaternary marine sediments of varied facies that are richly fossiliferous and often cyclically organized (Figures 2 and 3). The Italian late Neogene marine record has been important in introducing and defining CUs of the GTS and the construction of the ATS.

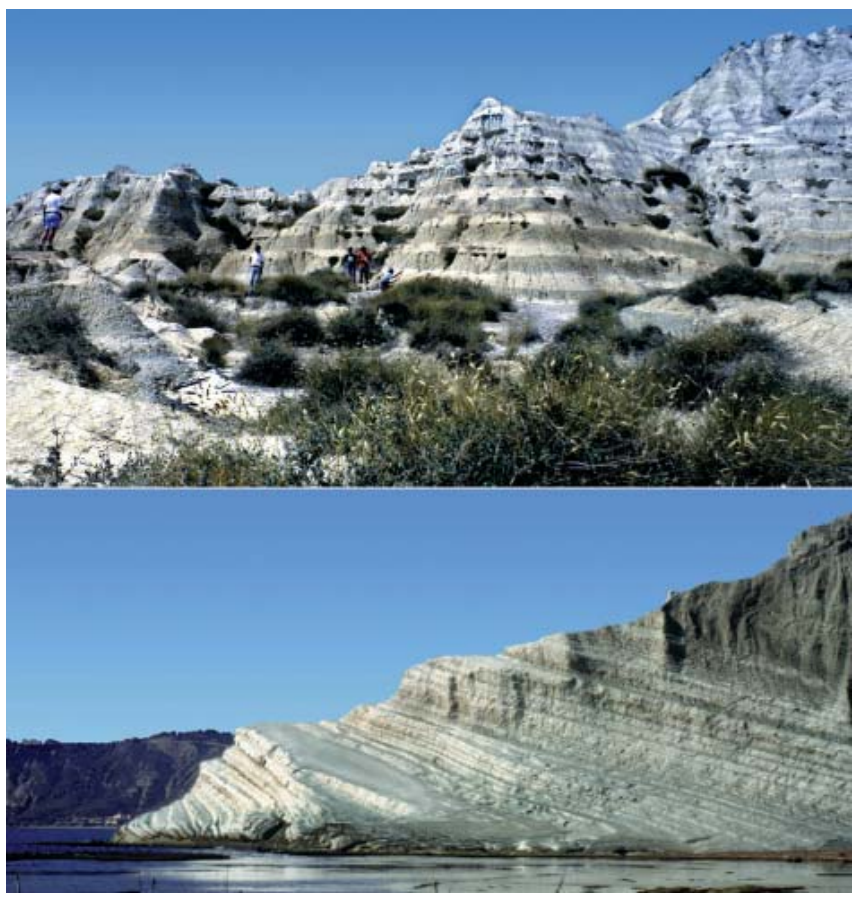

Figure 2 Orbitally-driven cyclicity in the Trubi Formation (Lower-Middle Pliocene) in Calabria (above) and Southern Sicily. (below).

\section{The Origins}

The first GTS (the Paleontological Time Scale) was established basically in England and in France. However, it has been mainly in Italy, during the Renaissance and the 17th and 18th centuries, that the true nature of fossils was strongly debated and understood by several scholars, such as Leonardo da Vinci (1452-1519), Agostino Scilla (1629-1700), Antonio Vallisneri (1661-1730), and many others. It was in Italy that the Danish scholar Niels Steensen (Steno) formulated in 1669 his principle of superposition of strata. Actually, the first rudimentary Geologic Time Scale might be considered to be that of Giovanni Arduino (1760), who subdivided the geologic record into the Primary, Secondary and Tertiary taking as reference the geology of northeastern and central Italy. In addition, Lyell (1833) and subsequent stratigraphers, in subdividing the Tertiary and Quaternary, made explicit reference to Italian localities as typical of their units. In most published GTSs, the subdivision of the Pleistocene into stages is entirely based on the Italian record (e.g. Calabrian, Sicilian, Tyrrhenian for quoting only the best known). In fact, most of standard stages of the Neogene, except those of the early Miocene, were also introduced with reference to the Italian record (Langhian, Serravallian, Tortonian, Messinian, Zanclean, Piacenzian, and the now obsolete Astian and Tabianian). 


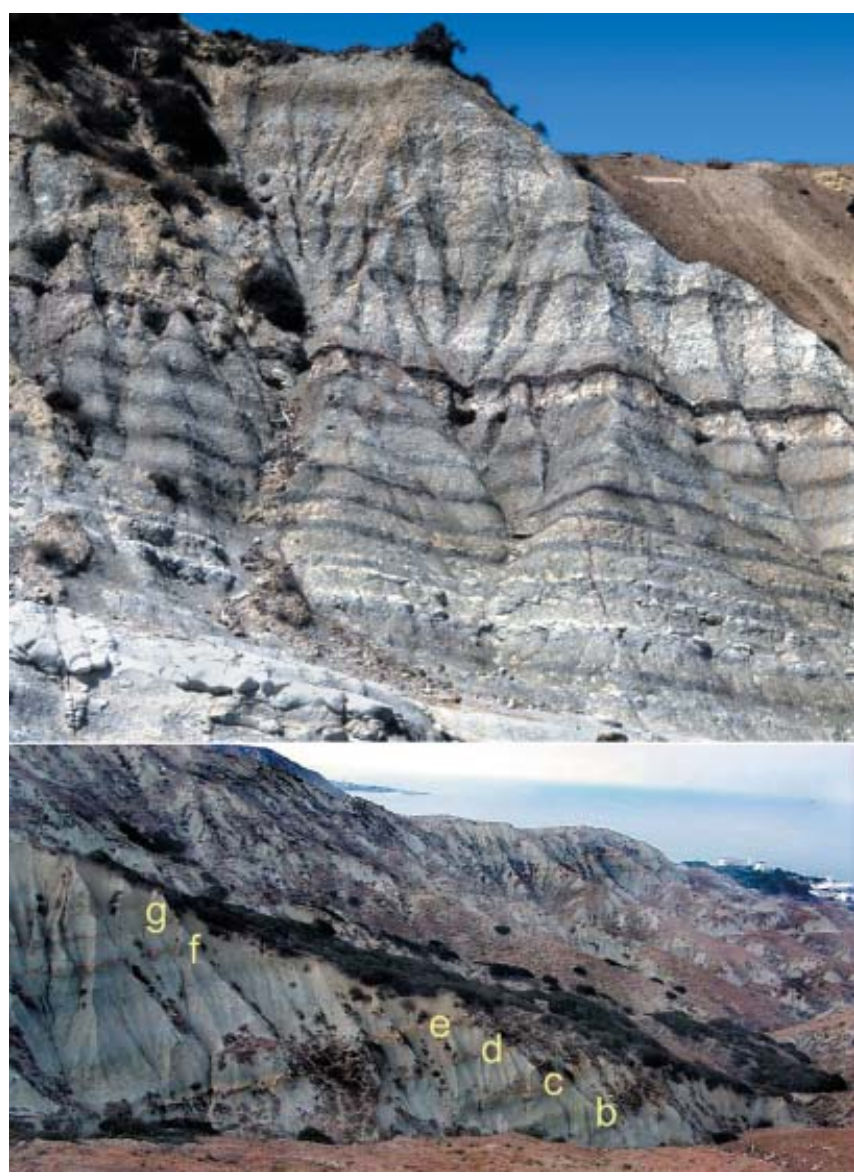

Figure 3 "Sapropels" in the Punta Piccola section, Sicily (Piacenzian GSSP, above) and in the Vrica section, Calabria (Pleistocene GSSP, below).

\section{Magnetobiochronology}

The globally synchronous reversals of geomagnetic field polarity were first revealed in dated basaltic lavas a few million years old. Volcanic events, however, occur irregularly and radiometric dates on discrete lavas becomes insufficiently precise to delineate polarity structure beyond $\sim 5 \mathrm{Ma}$; moreover, volcanic sequences can not easily be tied into the paleontologic scale. Therefore, major advances were achieved after the discovery in the 1960s that marine biogenic oozes and indurated pelagic sediments yield reliable magnetic signals. Combined investigations of paleomagnetic signals and calcareous plankton content from the same continuous pelagic successions allowed the construction of a magnetostratigraphy directly calibrated to multiple paleontologic scales. In this respect, Italian sections played a key role. The pelagic succession from the Umbria-Marche region provided in the 1970 s-early 1980 s an almost complete magnetobiochronology based on calcareous plankton for the entire Cretaceous up to the Paleogene/Neogene boundary. In particular, the Gubbio section in Umbria was proposed as the magnetostratigraphic type section for the Campanian to Upper Eocene interval (Alvarez et al., 1977). More recently, Cretaceous and Paleogene magnetobiochronology has been improved and updated based on successions from both the Umbria-Marche region and the Southern Alps (Premoli Silva et al., 1988). In the last few years the Italian stratigraphic record has proved important also for the magnetobiochronology of the Triassic System. By calibrating biohorizons based on conodonts and ammonites with magnetostratigraphy in Southern Alps and in Sicily, it has been possible to link the classical continental Newark succession with the marine-based GTS (Muttoni et al., 2001).

\section{Astrochronology}

The detailed paleoclimatic record of the Mediterranean has allowed the establishment of an accurate late Neogene ATS that has been based largely on the Italian marine records. Specifically, in the early 1990s, a composite reference section for the Pliocene-early Pleistocene ATS was established by splicing together the Rossello section in southern Sicily (Figure 2) and the Singa and Vrica (Figure 3) sections in Calabria (Hilgen et al., 1997). The derived astrochronology led to significant adjustments to the radiometry-based chronology of the most recent part of the GPTS (Cande and Kent, 1995). Today, the Mediterranean ATS has been extended to ca. 13 Ma (Krijgsman, 2002). The main feature utilized for astronomical tuning is the cyclicity of distinctive dark, organic-rich, often laminated layers known as sapropels (Figure 3). Mediterranean sapropels occur in clusters, which correspond to eccentricity maxima where individual sapropels correspond to insolation maxima associated with precession minima.

\section{GSSPs}

The formal definition of CUs by GSSPs has been a slow process, even if it has apparently accelerated in the last years. Even higher rank CUs are still undefined and, hence, often contradictorily used in the literature. According to Remane (in press) only one third of the Phanerozoic stages have been formally defined by GSSPs. It is worth mentioning that out of the 38 GSSPs so far defined, 7 are located in Italy, specifically the bases of the Oligocene, Miocene, Pliocene and Pleistocene Series and the three Stages of the Pliocene (Figure 4). All these GSSPs, except for the base of the Miocene, are located in sections calibrated with astrochronology thus providing unprecedented precision in definition. We refrain here to further comment on the defined Italian GSSPs since exhaustive information is available at the web site of the International Commission on Stratigraphy (ICS; www.micropress.org/stratigraphy/). We only comment below on work in progress for defining other GSSPs in the Italian stratigraphic record.

\section{The prospect}

We are sure that the Italian stratigraphic record preserves other important clues for implementing the GTS in terms of formal definitions of CUs (GSSPs), improving magnetobiochronology and extending downwards the ATS.

\section{Quaternary GSSPs}

Much work is in progress in southern Italy, where thick sections of early to middle Pleistocene marine sediments occur that can be firmly constrained in time with biomagnetostratigraphy (Rio et al., 1996) and stable oxygen isotope stratigraphy. In addition, these sections are characterized often by rich pollen contents, thus allowing a direct link between marine and continental stratigraphies and climates (Capraro et al., 2003). Some of these sections might prove useful for proposing GSSPs for the formal subdivision of the Quaternary (Italian Commission on Stratigraphy, 2002). The formal subdivision of the Quaternary is badly needed because the existing practice and informal proposals are so contradictory that the most recent GTS omits any subdivision (see the web site of ICS). There has been some discussion of defining Quaternary CUs in deep-sea sediment cores. We strongly oppose these proposals (except perhaps for the base of the Holocene) since there are so many impressive, well exposed and high quality marine records available on land in Italy, New Zealand, Japan and California. Others propose we should aban- 
don attempts to subdivide the Quaternary into stages. Again we strongly disagree and concur with Hedberg (1976, p. 82) that "the basic principles to be used in dividing the Quaternary into chronostratigraphic units should be the same as for the other Phanerozoic strata (...)".

\section{Other potential GSSPs}

In a recent overview by James Ogg (in Gradstein \& Ogg, 2002) some Italian sections are reported as candidates for the GSSPs of various CUs. Specifically, candidates GSSPs for the Chattian and Aptian have been indicated in the Umbria-Marche region, a candidate section for the Norian has been proposed in the Sicani Mountains of Sicily and candidate sections for the Carnian and Ladinian have been proposed in Southern Alps (Figure 4). Not reported in this compilation is the recent proposal of the Tortonian GSSP in Monte dei Corvi section (central Italy) made by Hilgen and coworkers. Our ongoing work in the Veneto region indicates potentially useful sections for defining the Bartonian and Priabonian.

\section{Magnetobiochronology and extending ATS}

Much work is going on in ODP and expected to continue in IODP for better resolving various microfossil biostratigraphic scales and their calibration to the GPTS, and for extending downwards the ATS. The latter task is particularly difficult because below ca. $25 \mathrm{Ma}$ we lack detailed knowledge of the correct astronomical solutions and new tuning strategies are needed (Pälike et al., 2001). However, we deem that the Italian stratigraphic record will continue to provide precious data. The marine Triassic of the Dolomites, Southern Alps and Sicily is being intensively studied (biomagnetostratigraphy and cyclostratigraphy) for a better definition of this geologic time interval unavailable in the deep sea. Work is continuing for improving magnetobiochronology and deciphering cyclostratigraphy in the Cretaceous and Paleogene records of Umbria-Marche regions. Our group has recently undertaken a systematic study of the Paleogene record of the Veneto region, where a continuous pelagic succession from the basal Paleocene to the late Priabonian is present with a spectacular cyclicity (Figure 5) that has been largely unexplored. The integration of the Italian records with others in the world will certainly contribute to our goal of better founding and better resolving the Geologic Time Scale.

\section{Acknowledgements}

Funding is from MIUR grants (PRIN 2002) to I. Premoli Silva and D. Rio. The paper has benefited from the critical reading by Dennis Kent, Maria Bianca Cita, and discussions with Simone Galeotti.

\section{References}

Alvarez, W., Arthur, M.A., Fischer, A.G., Lowrie, W., Napoleone, G., Premoli Silva, I. \& Roggenthen, W.M., 1977, Upper Cretaceous-Paleocene magnetic stratigraphy at Gubbio, Italy. Type section for the Late Cretaceous-Paleocene geomagnetic reversal time scale. Geological Society of America Bulletin, 88, pp. 383-389.

Arduino, G., 1750, Due lettere sopra varie osservazioni naturali dirette al Prof. A. Vallisnieri, Venezia.

Breggren, W.A., Kent, D.V., Swisher, C.C. \& Aubry, M.P., 1995, A revised Cenozoic geochronology and chronostratigraphy. SEPM Special Publication, 54, pp. 129-212.

Cande, S.C. \& Kent, D.V., 1995, Revised calibration of the geomagnetic polarity timescale for the Late Cretaceous and Cenozoic. Journal of Geophysical Research, 100, pp. 6093-6095.

Capraro, L., Bertoldi, R. \& Consolaro, C., 2003, Vegetational history across the middle Pleistocene Transition in the Central Mediterranean (Crotone

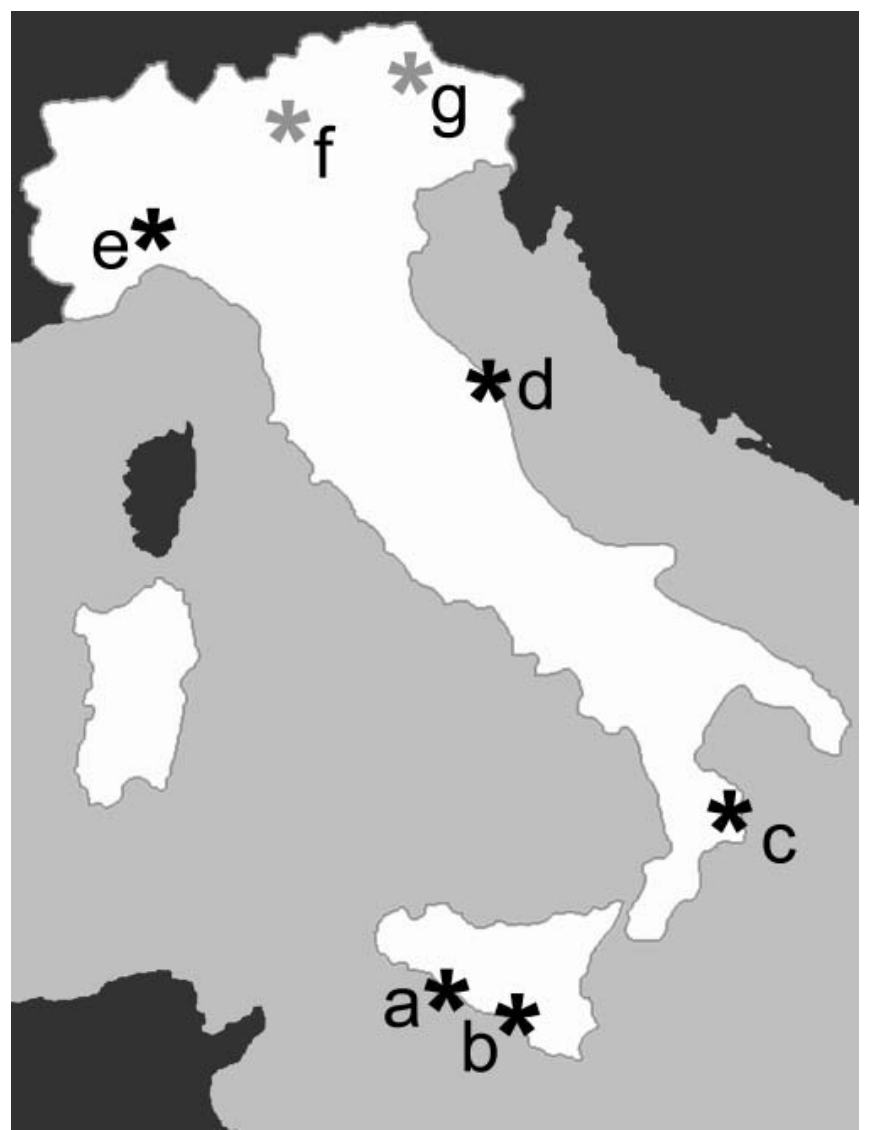

Figure 4 Location map of approved and candidate GSSPs in Italy.

a-Capo Rossello Composite Section (Sicily): Pliocene Series and Zanclean and Piacenzian Stages GSSPs;

b-Monte S. Nicola (Sicily): Gelasian Stage GSSP;

c-Vrica (Calabria): Pleistocene Series GSSP;

d-Massignano (Marche): Oligocene Series and Rupelian

Stage GSSP;

e-Lemme-Carrosio Section (Piedmont): Miocene Series and

Aquitanian Stage GSSP;

f-Bagolino (Central Southern Alps): candidate for the

Ladinian GSSP;

g-Prati di Stuores (Dolomites): candidate for the Carnian GSSP.

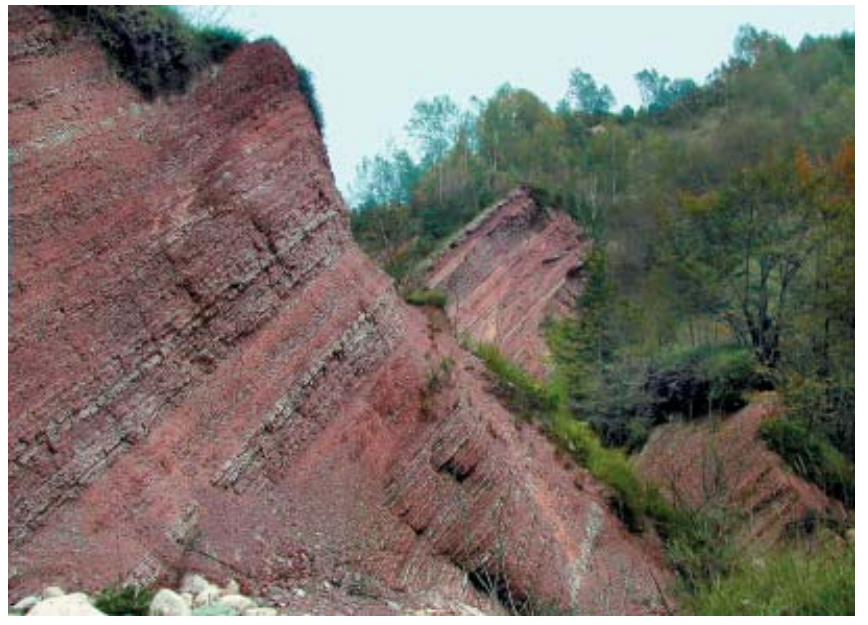

Figure 5 Early Eocene pelagic sediments cropping out in the Venetian Alps (Northeastern Italy). Integrated biomagnetostratigraphy is in progress, nevertheless the very meaning of this paramount cyclicity is still unexplored. 
Basin, Calabria, Southern Italy). Abstract, EGS-AGU-EUG Joint Assembly 2003, Nice, France.

Cowie, J.W., Ziegler, W., Boucot, A.J., Bassett, M.G., Remane, J., 1986, Guidelines and statutes of the International Commission on Stratigraphy (ICS). Courier Forschungsintitut Senckenberg, 83, 14 pp.

Gould, S.J., 1990, Time's arrow, Time's cycle: Myth and Metaphor in the Discovery of Geological Time. Penguin eds., Harmondsworth, 222 pp.

Gradstein, F. \& Ogg., J., 2002, Future Directions in Stratigraphy. Episodes, 25, p. 203.

Harland, W.B., Cox, A.V., Llevellyn, P.G., Pickton, C.A.G., Smith, A.G. \& Walters, R., 1982, A geologic time scale. Cambridge University Press, $131 \mathrm{pp}$.

Hedberg, H.D. (ed.), 1976, A guide to stratigraphic classification, terminology and procedures. Wiley \& Sons eds., New York, 200 pp.

Hilgen, F.J., Krijgsman, W., Langereis, C.G. \& Lourens, L.J., 1997, Breakthrough Made in Dating of the Geological Record. Eos, 78, pp. 288-289.

Holmes, A., 1960, A revised geological time-scale. Transactions of the Geological Society of Edinburgh, 17, pp. 183-216.

Italian Commission on Stratigraphy, 2002, Quaternary chronostratigraphy and the establishment of related standards. Episodes, 25, pp. 264-267.

Krijgsman, W., 2002, The Mediterranean: Mare Nostrum of Earth Sciences. Earth and Planetary Science Letters, 202, pp. 1-12.

Lowrie, W., Alvarez, W., Premoli Silva, I. \& Monechi, S., 1980, Lower Cretaceous magnetic stratigraphy in Umbrian pelagic carbonate rocks. Geophysical Journal of the Royal Astronomical Society, 60, pp. 263-281.

Lyell, C., 1833, Principles of Geology, 3. J. Murray eds., London, 550 pp.

Muttoni, G., Kent, D.V., Di Stefano, P., Gullo, M., Nicora, A., Tait, J. \& Lowrie, W., 2001, Magnetostratigraphy and biostratigraphy of the Carnian/Norian boundary interval from the Pizzo Mondello section (Sicani Mountains, Sicily). Palaeoclimatology, Palaeogeography, Palaeoecology, 166, pp. 383-399.

Pälike, H., Shackleton, N.J. \& Röhl, U., 2001, Astronomical forcing in Late Eocene marine sediments. Earth and Planetary Science Letters, 193, pp. 589-602.

Remane, J., in press, Chronostratigraphic correlations: their importance for the definition of geochronologic units. Palaeogeography, Palaeoclimatology, Palaeoecology, available online.

Rio, D., Channell, J. E. T., Massari, F., Poli, M. S., Sgavetti, M., D'Alessandro, A., \& Prosser, G., 1996, Reading Pleistocene eustasy in a tectonically active siliciclastic shelf setting (Crotone peninsula, southern Italy). Geology, 24, pp. 743-746.

Premoli Silva, I., Orlando, M., Monechi, S., Madile, M., Napoleone, G. \& Ripepe, M., 1988, Calcareous plankton biostratigraphy and magnetostratigraphy at the Eocene-Oligocene transition in the Gubbio area, in Premoli Silva, I., Coccioni, R. \& Montanari, A. (eds.), The Eocene-Oligocene boundary in the Marche-Umbria Basin (Italy). IUGS, Subcommission on Paleogene Stratigraphy, Ancona, Italy.

Snelling, N.J. (ed.), 1985, The chronology of the geological record. The Geological Society, Blackwell Scientific publications, $343 \mathrm{pp}$.

Steensen, N., 1669, De solido intra solidum naturaliter contento. Dissertationes prodromus, Firenze.
Domenico Rio is Professor of Paleontology at the University of Padova (Italy) and past Chairman of the Subcommission of Neogene Stratigraphy. His research includes calcareous nannofossil paleontology, Mediterranean Neogene stratigraphy and Northern Apennines geology. Presently he is working on Pleistocene climatic variability in the Mediterranean marine stratigraphic record and on the extreme climatic events in the Early Paleogene of the Southern Alps.

Isabella Premoli Silva is Professor of Micropaleontology at the University of Milan (Italy) and past Chairman of the Subcommission of Paleogene Stratigraphy. Her research includes detailed biostratigraphic studies of Cretaceous to Miocene planktonic foraminifers from land and deep-sea deposits. She has participated in seven cruises, in two as Co-Chief scientist, of the Deep Sea Drilling Project and Ocean Drilling Program. Her present research topics deal with the response and recovery of planktonic foraminifers to the extreme climatic warmth events of the Cretaceous and early Paleogene.

Luca Capraro is Assistant Researcher at the University of Padova (Italy). His research includes Pliocene and Pleistocene stratigraphy of the Mediterranean with a special emphasis in reconstructing the vegetational history and climatic variability of the Central Mediterranean during the middle Pleistocene climatic transition.
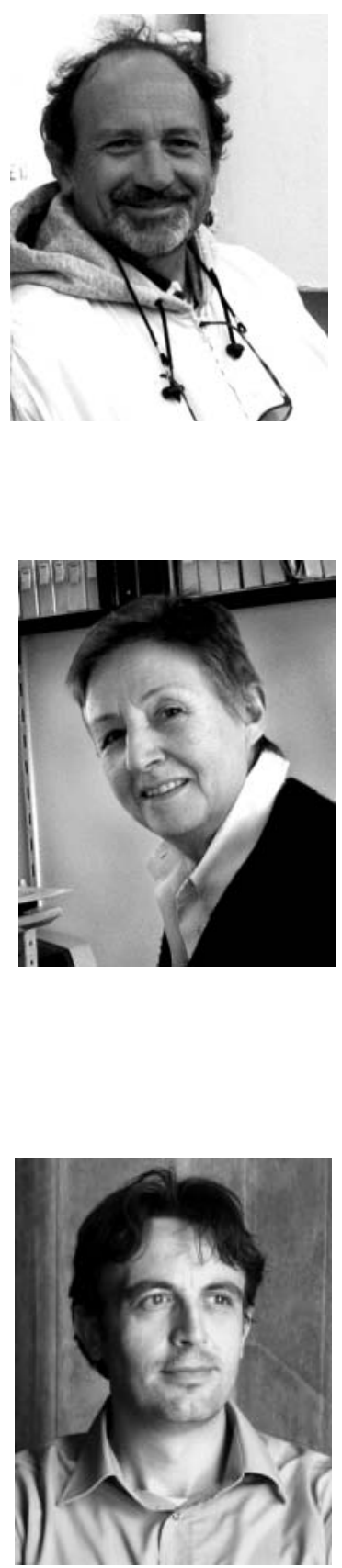